Cite this: New J. Chem., 2014, 38,817

Received (in Montpellier, France) 23rd August 2013,

Accepted 18th November 2013

DOI: $10.1039 / c 3 n j 00990 d$

www.rsc.org/njc

\section{Structure and properties of metal complexes of a pyridine based oxazolidinone synthesized by atmospheric $\mathrm{CO}_{2}$ fixation $\dagger$}

\author{
Amrita Sarkar, Sudipta Bhattacharyya, Suman Kr Dey, Subhendu Karmakar and \\ Arindam Mukherjee*
}

\begin{abstract}
We present here the synthesis of a pyridine containing oxazolidinone, 3-(pyridin-2-ylmethyl)oxazolidin2-one $(\mathrm{L})$ through the fixation of atmospheric $\mathrm{CO}_{2}$ and without any added base. $\mathrm{L}$ has been used to generate three metal complexes $\left[\mathrm{Cu}(\mathrm{L})_{2}\left(\mathrm{ClO}_{4}\right)_{2}\right](\mathbf{1})$, trans-[Pt $\left.(\mathrm{L})(\mathrm{DMSO}) \mathrm{Cl}_{2}\right](\mathbf{2})$, and trans- $\left[\mathrm{Pd}(\mathrm{L})_{2} \mathrm{Cl}_{2}\right](\mathbf{3})$. Complexes 1-3 have been structurally characterized using single crystal $\mathrm{X}$-ray diffraction and other analytical techniques. The activity studies of the three metal complexes show that the Cu" complex, 1, is more cytotoxic against the MCF-7 cancer cell line $\left(\mathrm{IC}_{50}=114 \pm 2 \mu \mathrm{M}\right)$ as compared to a non-carcinogenic mouse fibroblast (NIH 3T3) $\left(\mathrm{IC}_{50}=198 \pm 1 \mu \mathrm{M}\right)$. The Pt" complex, 2, is the most toxic among the three complexes against both human breast adenocarcinoma (MCF-7) $\left(\mathrm{IC}_{50}=102 \pm 2 \mu \mathrm{M}\right)$ and the human lung adenocarcinoma epithelial cell line (A549) $\left(\mathrm{IC}_{50}=198 \pm 2 \mu \mathrm{M}\right)$, whereas the $\mathrm{Pd}^{\prime \prime}$ complex, 3 , is found to be an effective first generation oxazolidinone based Pd" catalyst, for the Suzuki-Miyaura cross coupling of aryl halides and phenylboronic acids in aerobic conditions, both in a conventional heating method, as well as a microwave method. The results show that although $\mathrm{Pt}$ " and $\mathrm{Cu}^{\prime \prime}$ were also complexed with oxazolidinone, $\mathrm{Pd}^{\prime \prime}$ seems to be the most likely choice of metal when it comes to $\mathrm{C}-\mathrm{C}$ bond coupling via $\mathrm{C}-\mathrm{X}$ bond activation.
\end{abstract}

\section{Introduction}

Oxazolidinone compounds are of high interest for their potential as antimicrobial agents. Linezolid, the first oxazolidinone compound to be approved for clinical use, shows excellent antimicrobial activity against many important resistant pathogens. Eperezolid, radezolid, posizolid, and torezolid are some of the oxazolidinone class of compounds (Scheme 1), under clinical investigation, that are potent against bacterial infections. Cycloserine, an oxazolidinone derivative, is used for the treatment of tuberculosis when one or more drugs fails to treat the disease.

Apart from being antimicrobial compounds, oxazolidinone derivatives also are potential ligands from which to generate metal complexes. Metal complexes of oxazolidinones are known and have been used in catalysis viz. the Diels-Alder reaction, ${ }^{1-3}$ aldol reaction, ${ }^{4-6}$ Henry reaction, ${ }^{7}$ Mukaiyama-Michael reaction, ${ }^{8}$

Department of Chemical Sciences Indian Institute of Science Education \& Research Kolkata, Mohanpur Campus, P.O.-BCKV Main Campus, District-Nadia, 741252, India. E-mail: a.mukherjee@iiserkol.ac.in; Fax: +91-033-25873118; Tel: +91-033-25873121

$\dagger$ Electronic supplementary information (ESI) available: Crystallographic data in $\mathrm{CIF}$, schematic representation of catalytic cycle, ${ }^{1} \mathrm{H}-\mathrm{NMR},{ }^{13} \mathrm{C}-\mathrm{NMR}$ data of products in catalysis. CCDC 956432 (1) and 956433 (2). For ESI and crystallographic data in CIF or other electronic format see DOI: $10.1039 / \mathrm{c} 3$ nj00990d

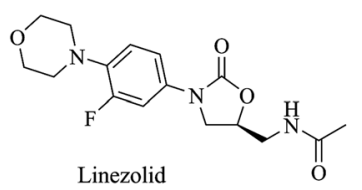

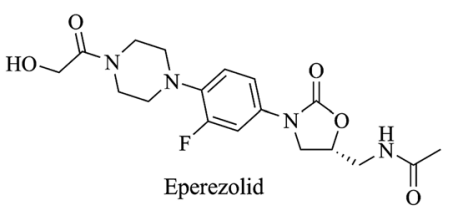<smiles>[R20]C([R4])=O</smiles><smiles>N[C@@H]1CONC1=O</smiles>

Scheme 1 Structure of oxazolidinone based drugs.

diamination of alkenes ${ }^{9,10}$ or to generate MOFs $^{11}$ mostly depending on the choice of metal and the coordination environment rendered. Although oxazolidinone based metal complexes have been used in catalysis, $\mathrm{C}-\mathrm{C}$ bond coupling via $\mathrm{C}-\mathrm{X}$ bond activation has never been attempted with oxazolidinone metal complexes. In addition, despite being of high therapeutic interest, oxazolidinones metal complexes have not been effectively probed as therapeutic agents (viz. antimicrobial or anticancer agents). ${ }^{12-14}$

From a synthetic point of view, oxazolidinone compounds can be obtained in various ways viz. using urea or epoxides, 


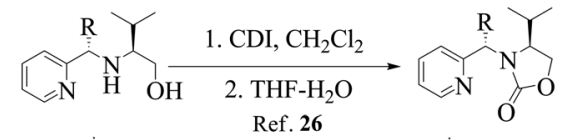

$$
\begin{aligned}
& \mathrm{R}=\text { allyl, }{ }^{\mathrm{i} P r}, \mathrm{EtMe}_{2} \mathrm{C} \quad \mathrm{R}=\text { allyl, }{ }^{\mathrm{i}} \mathrm{Pr}, \mathrm{EtMe}_{2} \mathrm{C}
\end{aligned}
$$

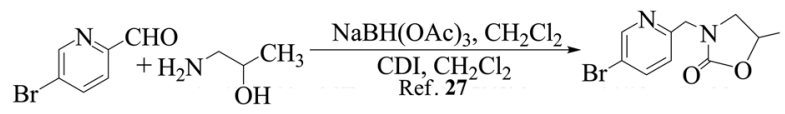

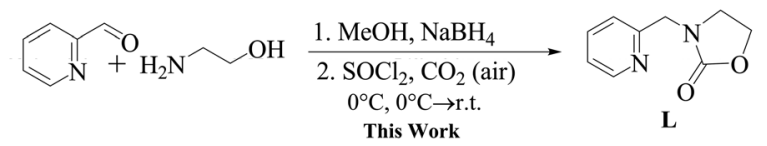

Scheme 2 Synthetic method of pyridine based oxazolidinone compounds reported earlier and ligand $L$ in this work.

along with amines, ${ }^{15-19}$ or from ethanolamine by purging $\mathrm{CO}_{2}$ gas, using the Mitsunobu reaction. ${ }^{20}$ There are also a few reports on the syntheses of oxazolidinones from amino alcohols with purging $\mathrm{CO}_{2}$ gas and using electrophiles and bases. ${ }^{21-25}$ However, the synthesis of oxazolidinone using air (which contains $\mathrm{CO}_{2}$ ) is not reported, although it should be possible, since air has a significant $\mathrm{CO}_{2}$ content. In addition pyridine containing oxazolidinones are a rare find $^{26,27}$ and no synthesis of pyridine containing oxazolidinone has been reported through the fixation of atmospheric $\mathrm{CO}_{2}$ (Scheme 2). If by using air, the atmospheric $\mathrm{CO}_{2}$ content could undergo reaction efficiently, then the lack of $\mathrm{CO}_{2}$ pressurized cylinders would represent a more convenient way of fixing $\mathrm{CO}_{2}$, through organic synthesis. Our interest in pyridine based oxazolidinones is due to their potential for metal chelation and possible use in therapeutics. ${ }^{28-34}$

In our attempt to generate a pyridine based oxazolidinone, we synthesized 3-(pyridin-2-ylmethyl)oxazolidin-2-one (L) in the presence of $\mathrm{SOCl}_{2}$ (Scheme 2) using air (atmospheric $\mathrm{CO}_{2}$ ) and without any added base. $\mathrm{L}$ is also a potential metal binder and hence, three metal complexes of the formulae $\left[\mathrm{Cu}(\mathrm{L})_{2}\left(\mathrm{ClO}_{4}\right)_{2}\right]$ (1), trans $-\left[\mathrm{Pt}(\mathrm{L})(\mathrm{DMSO}) \mathrm{Cl}_{2}\right](2)$, and trans $-\left[\mathrm{Pd}(\mathrm{L})_{2} \mathrm{Cl}_{2}\right]$ (3) were synthesized, to probe the potential of the newly designed pyridyl oxazolidinone ligand. Herein, we present the synthesis, structure and activity of the above three metal complexes, along with in vitro cytotoxicity studies against cancerous (MCF-7 and A549) and non-cancerous mouse fibroblast (NIH 3T3) cell lines.

Our work shows how the oxazolidinone and metal ions $(\mathrm{Cu}$, Pt, Pd) influence each other's chemistry, rendering the desired properties to the resultant complexes. 1 and $\mathbf{2}$ show toxicity against cancer cell lines, whilst the $\mathrm{Cu}^{\mathrm{II}}$ complex (1) is less toxic in the noncarcinogenic NIH 3T3 cell line. The palladium complex (3) is found to be a catalyst for the Suzuki-Miyaura coupling of aryl halides and phenylboronic acids in aerobic conditions, both in a conventional heating method as well as a microwave method. The results show that a metal complex of an oxazolidinone has the potential as a C-C bond cross coupling catalyst, or in therapeutics.

\section{Results}

\section{Preparation of ligands and complexes}

The three metal complexes synthesized with 3-(pyridin-2-ylmethyl)oxazolidin-2-one (L) bear different coordination environments

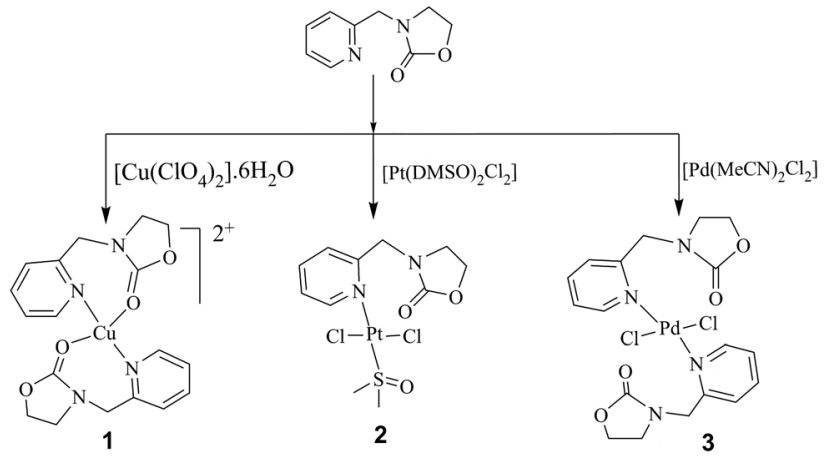

Scheme 3 Representative scheme for syntheses of metal complexes 1-3.

(Scheme 3). Complexes $\mathbf{1}$ and $\mathbf{3}$, having $\mathrm{Cu}^{\mathrm{II}}$ and $\mathrm{Pd}^{\mathrm{II}}$, react with two mole equivalent of $\mathrm{L}$, rendering complexes of the type $\mathrm{ML}_{2}$. Whereas, the $\mathrm{Pt}^{\mathrm{II}}$ containing complex 2 was formed by reaction with only one mole equivalent of the oxazolidinone ligand, in spite of having two mole equivalents of ligand per metal ion in the reaction solution. Once the composition became known we tuned the stoichiometry accordingly, providing a cleaner reaction and a better yield for 2 .

\section{X-ray crystallographic study of complexes 1-3}

The complexes 1-3 were characterized by single crystal X-ray crystallography. Complex 1 (Fig. 1) crystallizes in the monoclinic space group $P 2(1) / c$, and 2 in the triclinic space group $P \overline{1} .3$ crystallized in the monoclinic space group $P 2(1)$. However, although the crystal structure provides information about the structural nature of complex 3, is not publishable, due to relatively poor quality of the data. Single crystals suitable for X-ray crystallography were grown by the slow evaporation of an acetonitrile-methanol mixture (1:1) for the complex 1. For 2 (Fig. 2), layering a dichloromethane solution with hexane gave yellow needle shaped crystals, suitable for X-ray diffraction, whereas complex 3 gave orange coloured, block shaped crystals on the slow evaporation of an acetonitrile solution. The important crystallographic parameters for 1-3 and selected bond distances and angles of $\mathbf{1}$ and 2 have been summarised in Table S1 (ESI $\dagger$ ) and Table 1.

The copper complex 1 is $\mathrm{ML}_{2}$ type, with the $\mathrm{N}_{2} \mathrm{O}_{2}$ coordination bearing two weak axial linkages (ca. $2.75 \AA$, Fig. 1), with two

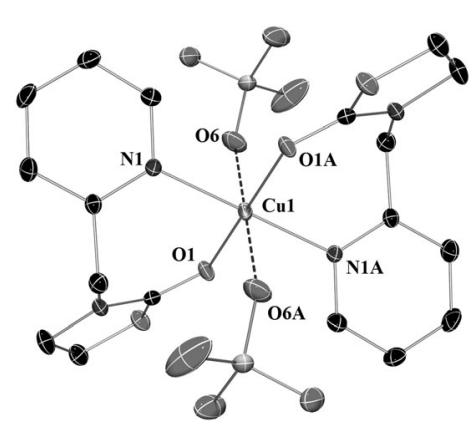

Fig. 1 Diagram of complex 1 with 50\% probability thermal ellipsoids. Hydrogen atoms have been omitted for clarity. Symmetry transformations used to generate equivalent atoms: $A=-x+1,-y,-z+2$. 


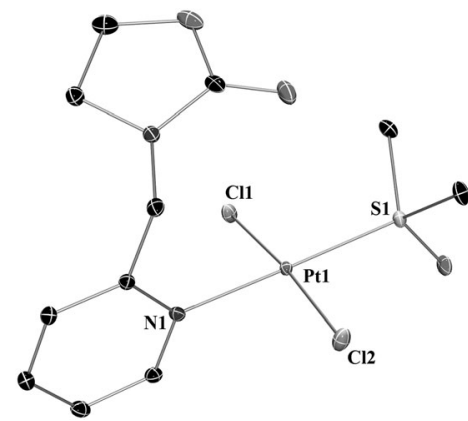

Fig. 2 Diagram of $\mathbf{2}$ showing one of two independent molecules in the asymmetric unit with $50 \%$ probability thermal ellipsoids. Hydrogen atoms and solvents have been omitted for clarity.

Table 1 Selected bond distances $(\AA)$ and angles $\left(^{\circ}\right)$ of complexes 1-2

\begin{tabular}{cccc}
\hline \multicolumn{1}{c}{1} & & 2 \\
\hline $\mathrm{Cu}(1)-\mathrm{N}(1)$ & $1.987(2)$ & $\mathrm{Pt}(1)-\mathrm{N}(1)$ & $2.057(3)$ \\
$\mathrm{Cu}(1)-\mathrm{O}(1)$ & $1.973(2)$ & $\mathrm{Pt}(1)-\mathrm{S}(1)$ & $2.2183(9)$ \\
$\mathrm{Cu}(1)-\mathrm{O}(6)$ & $2.75(2)$ & $\mathrm{Pt}(1)-\mathrm{Cl}(1)$ & $2.3025(8)$ \\
$\mathrm{N}(1)-\mathrm{Cu}(1)-\mathrm{N}(1 \mathrm{~A})^{a}$ & 180 & $\mathrm{Pt}(1)-\mathrm{Cl}(2)$ & $2.2965(9)$ \\
$\mathrm{O}(1)-\mathrm{Cu}(1)-\mathrm{O}(1 \mathrm{~A})^{a}$ & 180 & $\mathrm{Pt}(2)-\mathrm{N}(3)$ & $2.049(3)$ \\
$\mathrm{O}(1)-\mathrm{Cu}(1)-\mathrm{N}(1)$ & $93.75(9)$ & $\mathrm{Pt}(2)-\mathrm{S}(2)$ & $2.2182(8)$ \\
$\mathrm{O}(1)-\mathrm{Cu}(1)-\mathrm{N}(1 \mathrm{~A})^{a}$ & $86.25(9)$ & $\mathrm{Pt}(2)-\mathrm{Cl}(3)$ & $2.3019(9)$ \\
$\mathrm{N}(1)-\mathrm{Cu}(1)-\mathrm{O}(6)$ & $95.52(9)$ & $\mathrm{Pt}(2)-\mathrm{Cl}(4)$ & $2.3145(9)$ \\
$\mathrm{O}(1)-\mathrm{Cu}(1)-\mathrm{O}(6)$ & $107.66(8)$ & $\mathrm{N}(1)-\mathrm{Pt}(1)-\mathrm{S}(1)$ & $178.16(8)$ \\
$\mathrm{N}(1 \mathrm{~A})^{a}-\mathrm{Cu}(1)-\mathrm{O}(6)$ & $84.48(9)$ & $\mathrm{N}(1)-\mathrm{Pt}(1)-\mathrm{Cl}(1)$ & $88.22(8)$ \\
$\mathrm{O}(1 \mathrm{~A})^{a}-\mathrm{Cu}(1)-\mathrm{O}(6)$ & $72.34(8)$ & $\mathrm{S}(1)-\mathrm{Pt}(1)-\mathrm{Cl}(1)$ & $90.66(3)$ \\
& & $\mathrm{N}(1)-\mathrm{Pt}(1)-\mathrm{Cl}(2)$ & $88.27(8)$ \\
& & $\mathrm{S}(1)-\mathrm{Pt}(1)-\mathrm{Cl}(2)$ & $92.97(3)$ \\
& & $\mathrm{Cl}(1)-\mathrm{Pt}(1)-\mathrm{Cl}(2)$ & $174.09(3)$ \\
& & $\mathrm{N}(3)-\mathrm{Pt}(2)-\mathrm{S}(2)$ & $179.13(8)$ \\
& $\mathrm{N}(3)-\mathrm{Pt}(2)-\mathrm{Cl}(3)$ & $87.30(8)$ \\
& & $\mathrm{S}(2)-\mathrm{Pt}(2)-\mathrm{Cl}(3)$ & $92.14(3)$ \\
& & $\mathrm{N}(3)-\mathrm{Pt}(2)-\mathrm{Cl}(4)$ & $88.33(8)$ \\
& & $\mathrm{S}(2)-\mathrm{Pt}(2)-\mathrm{Cl}(4)$ & $92.26(3)$ \\
& & $\mathrm{Cl}(3)-\mathrm{Pt}(2)-\mathrm{Cl}(4)$ & $175.23(3)$ \\
& &
\end{tabular}

oxygen atoms of two perchlorate anions making the co-ordination environment an elongated octahedral type (Fig. 1). Whereas, complex 2 showed the $\mathrm{Pt}^{\mathrm{II}}$ to be in a trans geometry, with one $\mathrm{L}$ per molecule (Fig. 2). The trans-Pt $\mathrm{Pt}^{\mathrm{II}}$ in complex 2 is coordinated via the pyridine $\mathrm{N}$. Unlike the $\mathrm{Cu}^{\mathrm{II}}$ complex, the carbonyl oxygen is not bound to $\mathrm{Pt}^{\mathrm{II}}$. There are two trans $\mathrm{Cl}^{-}$ligands along with a DMSO, bound to the $\mathrm{Pt}^{\mathrm{II}}$ centre via the sulphur atom. On the other hand complex 3 is also a trans complex of $\mathrm{Pd}^{\mathrm{II}}$, with two ligands trans to each other and two chlorides as found from the crystallographic studies, but the structural details are not presented, here since the data obtained do not render a fully publishable structure.

\section{Lipophilicity measurement}

The partition coefficients between octanol and an aqueous buffer layer, to determine the lipophilicity of the three complexes (1-3), were calculated using the well known formula of $\log P=$ $C_{\text {oct }} / C_{\text {aq }}$, where $C_{\text {oct }}$ was the concentration of the complex in the organic layer and $C_{\mathrm{aq}}$ was the concentration of the complex in the phosphate buffer $(20 \mathrm{mM})$ found through UV-visible spectroscopy. The results (Fig. 3 and Table 2) show the lipophilicity, or

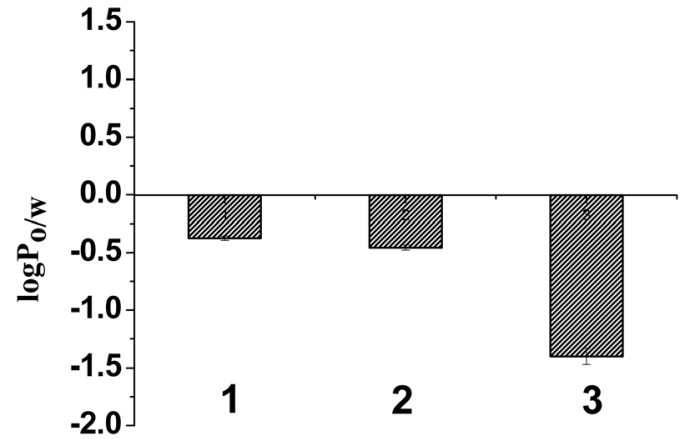

Fig. 3 Lipophilicity of complexes 1-3 represented by a bar diagram showing comparative $\log P$ values of $1-3$ in octanol-water system, where error bars in the graph represent the standard deviation in measurement.

Table $2 \log P$ values of complexes 1-3 in octanol-water system

\begin{tabular}{ll}
\hline Compound & $\log P_{\mathrm{o} / \mathrm{w}}{ }^{a}$ \\
\hline $\mathbf{1}$ & $-0.37574(1)$ \\
$\mathbf{2}$ & $-0.45707(2)$ \\
$\mathbf{3}$ & $-1.40328(2)$ \\
${ }^{a}$ The value in parentheses shows & standard error. Experiments were \\
carried out in triplicate. &
\end{tabular}

the $\log P_{\mathrm{o} / \mathrm{w}}$ for the complexes 1-3. We found that all three complexes are hydrophilic in nature and complex $\mathbf{3}$ is the most hydrophilic among the three complexes. The lipophilicity order is $\mathbf{1}>\mathbf{2}>\mathbf{3}$.

\section{Cell cytotoxicity}

The complexes 1-3 were tested in vitro against a human breast adenocarcinoma cell line (MCF-7) and a human lung adenocarcinoma epithelial cell line (A549) as well as a mouse embryonic fibroblast cell line (NIH 3T3) by the MTT assay, where cisplatin was used as a standard in each 96 well plate. The data show that the ligand $\mathrm{L}$ has an $\mathrm{IC}_{50}$ value greater than $1000 \mu \mathrm{M}$ in the MCF-7 cell line, so it was not probed in the A549 and NIH 3T3 cell lines. Among the three metal complexes, the trans-platinum complex 2 shows the highest cytotoxicity in the MCF-7 cell line $\left(\mathrm{IC}_{50}=102 \pm 2 \mu \mathrm{M}\right)$, whereas in the A549 cell line, the $\mathrm{IC}_{50}$ is $198 \pm 2 \mu \mathrm{M}$. The $\mathrm{IC}_{50}$ of the $\mathrm{Cu}^{\mathrm{II}}$ complex 1 in MCF-7 is $114 \pm 2 \mu \mathrm{M}$ and in A549 it is $455 \pm 3 \mu \mathrm{M}$, respectively. In the MCF 7 cell line, the palladium complex 3 shows an $\mathrm{IC}_{50}$ $260 \pm 3 \mu \mathrm{M}$, but in the A549 cell line, it is $236 \pm 1 \mu \mathrm{M}$. In the non-cancerous NIH 3T3 cell line, the copper complex 1 is less toxic, with an $\mathrm{IC}_{50}$ of $198 \pm 1 \mu \mathrm{M}$, as compared to the MCF-7 cancer cell line. The same is not true for the well known drug cisplatin or the new synthons, complexes $\mathbf{2}$ and $\mathbf{3}$ reported here (Table 3). The obtained data were plotted and fitted using GraphPad Prism $5^{\circledR}$ Ver 5.03 (Fig. S1-S3, ESI $\dagger$ ). The $\mathrm{IC}_{50}$ values are summarised in Table 3.

\section{Suzuki-Miyaura cross coupling catalyzed by palladium complex (3)}

The Suzuki-Miyaura coupling reactions between various aryl halides and phenylboronic acid catalyzed by the complex 3 were 
Table 3 Cytotoxicity of ligand L and complexes 1-3 on MCF-7, A549 and $\mathrm{NIH} 3 \mathrm{~T} 3$ cell lines from three experimental trials with comparison to cisplatin, carboplatin and cyclophosphamide

\begin{tabular}{|c|c|c|c|}
\hline \multirow[b]{2}{*}{ Compounds } & \multicolumn{3}{|c|}{$\underline{\mathrm{IC}_{50}(\mu \mathrm{M}) \pm \mathrm{SD}^{a}}$} \\
\hline & MCF-7 & A549 & NIH 3T3 \\
\hline $\mathrm{L}$ & $>1000$ & n.d. & n.d. \\
\hline 1 & $114 \pm 2$ & $455 \pm 3$ & $198 \pm 1$ \\
\hline 2 & $102 \pm 2$ & $198 \pm 2$ & $41 \pm 1$ \\
\hline 3 & $260 \pm 3$ & $236 \pm 3$ & $151 \pm 1$ \\
\hline Cisplatin & $14 \pm 1$ & $21 \pm 2$ & $11 \pm 2$ \\
\hline Carboplatin $^{b}$ & 62.19 & - & - \\
\hline Cyclophosphamide & $>3000$ & n.d. & $>3000$ \\
\hline \multicolumn{4}{|c|}{$\begin{array}{l}{ }^{a} \mathrm{SD}=\text { standard deviation; } \mathrm{IC}_{50} \text { values were calculated by variable slope } \\
\text { model using GraphPad Prism } 5^{\mathbb{R}} \cdot 6 \times 10^{3} \text { cells per well were treated for } \\
48 \mathrm{~h} \text { with increasing concentrations of tested compounds. }{ }^{b} \text { On drug } \\
\text { exposure of } 72 \mathrm{~h} . .^{35}\end{array}$} \\
\hline
\end{tabular}

carried out both with a conventional heating method, as well as a microwave method. All the reactions were carried out in atmospheric conditions, as the palladium catalyst is stable in air. For both cases, the temperature was $80{ }^{\circ} \mathrm{C}$. We optimized the solvent system by varying the solvents among water, ethanol and acetonitrile. Ethanol was preferred as the solvent, since the precipitation of palladium black, which may indicate the degradation of the catalyst, was less. The catalytic results were also good in water, but the precipitation of palladium black during catalysis was more in an aqueous medium (Table S2, ESI $\dagger$ ). The reaction in the presence of various bases provided the information that the best results were obtained in the presence of $\mathrm{Cs}_{2} \mathrm{CO}_{3}$ (Table 4). The test reaction used in these cases was the cross coupling between 4-bromoanisole and phenylboronic acid (Table 4).

Hence forth, $\mathrm{Cs}_{2} \mathrm{CO}_{3}$ was used as the base and the coupling reactions were performed using various aryl halides with phenylboronic acid in an EtOH medium, by both the conventional heating method and microwave irradiation methods. The catalyst loading was varied from $0.2 \mathrm{~mol} \%$ to $1 \mathrm{~mol} \%$, with respect to the aryl halides. The results are tabulated in Tables 5 and 6 . The results show that the catalytic activity depends on the nature of the aryl halides, which is a well known fact. ${ }^{36}$ With variation of the substitution in the aryl ring, the rate of reaction also varied significantly i.e. 4-bromoacetophenone gave complete

Table 4 Screening of bases for the reaction of 4-bromoanisole and phenylboronic acid ${ }^{a}$

\begin{tabular}{lll}
\hline & & \\
\hline Entry & Base & Yield $^{b}(\%)$ \\
\hline 1 & $\mathrm{Cs}_{2} \mathrm{CO}_{3}$ & 92 \\
2 & $\mathrm{~K}_{2} \mathrm{CO}_{3}$ & 80 \\
3 & $\mathrm{~K}_{3} \mathrm{PO}_{4}$ & 56 \\
4 & $\mathrm{Bu}_{4} \mathrm{NOH}_{2} \mathrm{hr}$ & 74 \\
5 & $(i \mathrm{Pr})_{2} \mathrm{EtN}$ & 52 \\
6 & $\mathrm{NaOMe}$ & 67
\end{tabular}

${ }^{a}$ Reaction conditions: 4-bromoanisole ( $\left.0.093 \mathrm{~g}, 0.5 \mathrm{mmol}\right)$, phenylboronic acid $(0.0915 \mathrm{~g}, 0.75 \mathrm{mmol})$, base $(1.5 \mathrm{mmol}), \mathrm{EtOH}(5 \mathrm{~mL}) .{ }^{b}$ Isolated yield after column chromatography.
Table 5 Suzuki-Miyaura cross coupling between aryl halides and phenylboronic acid with conventional heating method $\left(80^{\circ} \mathrm{C}\right)^{a}$

\begin{tabular}{|c|c|c|c|c|c|}
\hline Entry & Aryl halide & $\begin{array}{l}\text { Catalyst } \\
\text { loading (mol\%) }\end{array}$ & Time & $\begin{array}{l}\text { Isolated } \\
\text { yield (\%) }\end{array}$ & $\mathrm{TOF}^{b}$ \\
\hline 1 & & 0.2 & $20 \mathrm{~min}$ & $>99$ & 1515 \\
\hline 2 & $\mathrm{H}_{3} \mathrm{C}$ & 0.2 & $30 \mathrm{~min}$ & $>99$ & 1000 \\
\hline 3 & $\mathrm{H}_{3} \mathrm{CO}$ & 0.2 & $30 \mathrm{~min}$ & $>99$ & 1000 \\
\hline 4 & $\mathrm{H}_{3} \mathrm{CO}$ & 1.0 & $2 \mathrm{~h}$ & 92 & 46 \\
\hline 5 & $\mathrm{H}_{3} \mathrm{COC}$ & 0.5 & $1 \mathrm{~h}$ & 97 & 194 \\
\hline 6 & $\mathrm{O}_{2} \mathrm{~N}^{-}$ & 0.5 & $1 \mathrm{~h}$ & 99 & 198 \\
\hline 7 & $\mathrm{NC}^{-}$ & 0.5 & $30 \mathrm{~min}$ & 95 & 380 \\
\hline 8 & & 1.0 & $4 \mathrm{~h}$ & $>99$ & 24 \\
\hline 9 & $\mathrm{H}_{3} \mathrm{CO}^{-}$ & 2.0 & $12 \mathrm{~h}$ & - & - \\
\hline
\end{tabular}

${ }^{a}$ Reaction conditions: aryl halides $(0.5 \mathrm{mmol})$, phenylboronic acid (0.0915 g, $0.75 \mathrm{mmol}), \mathrm{Cs}_{2} \mathrm{CO}_{3}(0.48 \mathrm{~g}, 1.5 \mathrm{mmol})$ EtOH $(5 \mathrm{~mL})$. ${ }^{b}$ TOF $\left(\mathrm{h}^{-1}\right)$.

conversion to its corresponding biaryl in an hour using $0.5 \%$ catalyst at $80{ }^{\circ} \mathrm{C}$ (Table 5, entry 5), whereas 4-bromoanisole needed 2 hours for complete conversion, using $1 \mathrm{~mol} \%$ catalyst and $80{ }^{\circ} \mathrm{C}$ (Table 5, entry 4). A similar trend was observed using the microwave method. We found that the microwave method improved the TOF, since the reaction completion time decreased (Table 6). The TOF (turn over frequency) was calculated using the formula, TOF $\left(\mathrm{h}^{-1}\right)=$ (no of moles of the product formed $) /\{($ no of moles of the catalyst involved) $\times$ (reaction time for completion in hour) $\}.{ }^{37}$ The yields reported in the table are the isolated yields, after individual column chromatography.

\section{Discussion}

There have been several reports where 2-oxazolidinones were formed from amino ethanol derivatives by the purging of $\mathrm{CO}_{2}$ and the addition of electrophiles and bases. ${ }^{20-24}$ Earlier work to form pyridine based oxazolidinone was mostly done with preformed oxazolidinone derivatives. ${ }^{38,39}$ A recent report, using non-pyridine substrates, showed that in the presence of $\mathrm{SOCl}_{2}$ and a base, 1,2 amino alcohols can form oxazolidinones with the inversion or retention of the configuration, ${ }^{24}$ depending on the substituents. Based on that proposed mechanism, we should obtain an inversion of the configuration during product formation and indeed, we obtained the inverted product in a major yield, although unlike the earlier report, we had no added base to our 
Table 6 Suzuki-Miyaura cross coupling between aryl halides and phenylboronic acid with microwave irradiation ${ }^{a}$

\begin{tabular}{|c|c|c|c|c|c|}
\hline Entry & Aryl halide & $\begin{array}{l}\text { Catalyst } \\
\text { loading (mol\%) }\end{array}$ & Time & $\begin{array}{l}\text { Isolated } \\
\text { yield }(\%)\end{array}$ & $\mathrm{TOF}^{b}$ \\
\hline 1 & & 0.2 & $10 \mathrm{~min}$ & $>99$ & 3000 \\
\hline 2 & $\mathrm{H}_{3} \mathrm{C}$ & 0.2 & $10 \mathrm{~min}$ & $>99$ & 3000 \\
\hline 3 & $\mathrm{H}_{3} \mathrm{CO}$ & 0.2 & $10 \mathrm{~min}$ & $>99$ & 3000 \\
\hline 4 & $\mathrm{H}_{3} \mathrm{CO}^{-}$ & 1.0 & $30 \mathrm{~min}$ & 84 & 168 \\
\hline 5 & $\mathrm{H}_{3} \mathrm{COC}$ & 0.5 & $20 \mathrm{~min}$ & 98 & 588 \\
\hline 6 & $\mathrm{O}_{2} \mathrm{~N}^{-}$ & 0.5 & $15 \mathrm{~min}$ & 92 & 736 \\
\hline 7 & $\mathrm{NC}^{-}$ & 0.5 & $15 \mathrm{~min}$ & 98 & 784 \\
\hline 8 & & 1.0 & $30 \mathrm{~min}$ & $>99$ & 198 \\
\hline 9 & $\mathrm{H}_{3} \mathrm{CO}^{-}$ & 2.0 & $2 \mathrm{~h}$ & - & - \\
\hline
\end{tabular}

${ }^{a}$ Reaction conditions: aryl halides $(0.5 \mathrm{mmol})$, phenylboronic acid (0.0915 g, $0.75 \mathrm{mmol}), \mathrm{Cs}_{2} \mathrm{CO}_{3}(0.48 \mathrm{~g}, 1.5 \mathrm{mmol})$, EtOH $(5 \mathrm{~mL})$. Microwave temperature $80^{\circ} \mathrm{C}$, max pressure $=8 \mathrm{bar}$, max power $=46 \mathrm{~W}$. ${ }^{b}$ TOF $\left(\mathrm{h}^{-1}\right)$.

reaction. However, the yield is $60 \%$ and hence the pyridine substrate may also be acting as a base. ${ }^{24}$ We carried out the reaction in $\mathrm{SOCl}_{2}$, which serves as an electrophile and the presence of atmospheric $\mathrm{CO}_{2}$ lead to carbonylation, without any additional base. Based on the earlier proposed mechanism, we propose the formation of a transient carbamate species, by the incorporation of $\mathrm{CO}_{2}$, without any added base and the pyridine moiety in the substrate may stabilise the species. In the presence of $\mathrm{SOCl}_{2}$, the hydroxyl oxygen of the amino alcohol is activated and becomes a good leaving group, which then suffers a nucleophilic attack from a carbamate oxygen, forming the oxazolidinone ring. The mechanistic proposal is depicted in Scheme 4.

The single crystal structures of 1, 2 and 3 showed that metal complexes of a varying ligand to metal stoichiometry are formed.

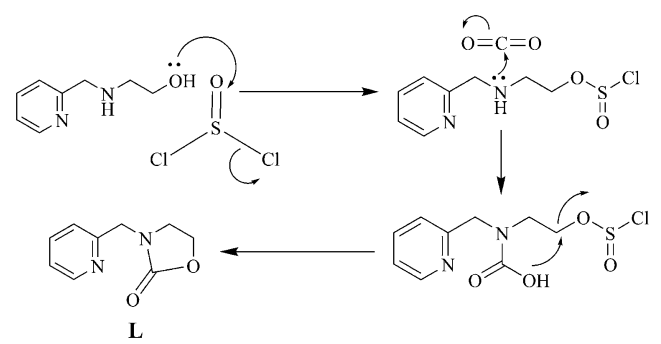

Scheme 4 Mechanistic proposal for preparation of ligand L.
In complexes 1 and 3 , the metal to ligand (L) ratio was 1:2, whereas in 2 it was $1: 1$. The unique electronic property of the metal leads to a difference in the dissociation of the labile ligands, leading to a change in the reactivity and redox properties.

We probed the reactivity with $\mathbf{3}$ for $\mathrm{C}-\mathrm{C}$ bond cross coupling as a proof of concept, since $\mathrm{Pd}(\mathrm{OAc})_{2}(5-10 \mathrm{~mol} \%)$ itself can act as a catalyst for the same purpose. Palladium catalyzed SuzukiMiyaura cross coupling reactions between organic halides with aryl boronic acid are the most effective and widely used method for the synthesis of various biaryls. ${ }^{40-45} \mathrm{Pd}^{\mathrm{II}}$ complexes of phosphane based ligands have been among the most effective ones to perform the Suzuki-Miyaura cross coupling reactions. ${ }^{46-53}$ The search for alternative ligands has seen a surge during the past and present decade, ${ }^{54-58}$ due to the sensitivity and nonenvironmentally friendly nature of phosphane based catalysts. Efficient catalysts for the Suzuki-Miyaura reaction have been made using N-heterocyclic carbene ligands, ${ }^{59-67}$ palladacycles ${ }^{68-70}$ and other ligand systems. ${ }^{71-73}$ However, the use of oxazolidinone as a ligand for such catalysis is unknown. Our work shows that oxazolidinone has the potential as a ligand to palladium, to generate catalysts for $\mathrm{C}-\mathrm{C}$ bond cross coupling, using aryl halides and phenylboronic acids.

Complex 3 act as a good catalyst for the Suzuki-Miyaura cross-coupling reaction of different aryl halides viz. bromides and iodides with different electron donating and withdrawing groups in the para and ortho positions, in considerably good yields. For aryl iodides, with only $0.2 \mathrm{~mol} \%$ catalyst loading, we obtained almost full conversion, in 20-30 min, whereas for aryl bromides, we had to increase the catalyst loading to $0.5-1.0 \%$, to afford a full conversion, in $0.5-1.0 \mathrm{~h}$. This observation can be well argued, since iodide is a better leaving group than bromide. Electronic factors play an important role for the reaction of aryl halides containing electron donating and electron withdrawing groups. An electron withdrawing substituent present in the ortho or para position of the aryl halide favours the reaction, thus the rate of reaction increases, while in the presence of an electron donating substituent, the rate of reaction decreases as it strengthens the $\mathrm{C}-\mathrm{X}$ bond. Thus, for 4-acetyl, 4-nitro and 4-cyanophenylbromides, with $0.5 \mathrm{~mol} \%$ catalyst loading, we obtained excellent yields within 30 minutes to 1.0 hours (Table 5 , entries $5-7$ ), but for 4 -bromoanisole it needed 2 hours for a complete conversion, using $1 \mathrm{~mol} \%$ catalyst and $80{ }^{\circ} \mathrm{C}$ (Table 5, entry 4). Using a microwave reactor, we observed the same trend, although here the completion of reaction is achieved within 10-30 min. Hence, the microwave method is better than the conventional heating method. However, for aryl chlorides we did not get the desired product, even after 12 hours, hence the Pd complex 3 could not serve as a catalyst for the Suzuki-Miyaura coupling of aryl chlorides (Tables 5 and 6, entry 9). The results are still important and encouraging, since the catalytic $\mathrm{C}-\mathrm{C}$ bond cross coupling reaction using $\mathrm{L}$ is at its infancy. Complex 3 is proposed to follow the general mechanistic pathway via oxidative addition, transmetalation and reductive elimination reported in the literature for $\mathrm{C}-\mathrm{C}$ bond cross coupling via $\mathrm{C}-\mathrm{X}$ bond activation (Scheme S1, ESI $\dagger)^{40,41,74}$ 
$\mathrm{L}$ was also probed for its potential as a ligand in therapeutics. In vitro studies of $\mathrm{L}$ complexed with $\mathrm{Cu}^{\mathrm{II}}$ (1) and $\mathrm{Pt}^{\mathrm{II}}$ (2) show anticancer activity, with an $\mathrm{IC}_{50}$ of $114 \pm 2 \mu \mathrm{M}$ for 1 and $102 \pm 2 \mu \mathrm{M}$ for 2 in the MCF-7 cancer cell line. 1 is less toxic in the non-cancerous mouse cell line (NIH 3T3) $\left(\mathrm{IC}_{50}=198 \pm 1 \mu \mathrm{M}\right)$ in vitro, as compared to its toxicity over MCF-7, which is encouraging, since the well known drug cisplatin, which has a much lower $\mathrm{IC}_{50}$ value in MCF-7 or A549, does not exhibit this property. However, the $\mathrm{Pt}^{\mathrm{II}}$ complex 2 is relatively more active against the lung cancer cell line (A549), showing an $\mathrm{IC}_{50}$ of $198 \pm 1 \mu \mathrm{M}$ when compared to $1\left(\mathrm{IC}_{50}=455 \pm 3 \mu \mathrm{M}\right)$. The in vitro toxicity data show that the trans-Pt complex is most potent $\left(\mathrm{IC}_{50}=102 \pm 2 \mu \mathrm{M}\right.$ in MCF-7) among the three metal complexes. The palladium complex is the least active with $\mathrm{IC}_{50}$ values $>$ $200 \mu \mathrm{M}$ and it is the most hydrophilic among the three candidates. 3 is more active over the A549 cell line $\left(\mathrm{IC}_{50}=236 \pm 3 \mu \mathrm{M}\right)$, compared to MCF-7 ( $\left.\mathrm{IC}_{50}=260 \pm 3 \mu \mathrm{M}\right)$, but at the same time it is also more toxic to the non-cancerous mouse NIH 3T3 cell line $\left(\mathrm{IC}_{50}=151 \pm 1 \mu \mathrm{M}\right)$. trans $-\mathrm{Pt}^{\mathrm{II}}$ compounds are, in general, less reactive than cis- $\mathrm{Pt}^{\mathrm{II}}$ compounds and the in vitro data are in accordance with the known literature. The dose required to achieve a $50 \%$ killing is high for the series of complexes, as compared to many drugs already in the clinic. However, it is encouraging to see that there are drugs which are widely used in the clinic, or are in clinical trials and have in vitro toxicity data from which they seem apparently much less potent (viz. in vitro IC $_{50}$ values: cyclophosphamide $>1000 \mu \mathrm{M}$ on MCF-7, ${ }^{75}$ gallium nitrate in the range $60-250 \mu \mathrm{M}$ in HCC lines, ${ }^{76}$ ruthenium based compounds NAMI-A $>500 \mu \mathrm{M}$ in the MCF-7 cell line ${ }^{77,78}$ and RAPTA-C $>350 \mu \mathrm{M}$ in the A2780 cell line ${ }^{79}$ ). In fact, when we tested cyclophosphamide against MCF-7, we could not reach an $\mathrm{IC}_{50}$ value, even at a $3000 \mu \mathrm{M}$ concentration of the drug. Hence, it should be noted that having a lower $\mathrm{IC}_{50}$ does not necessarily mean that the complex would be a better drug candidate, rather the unwanted side effects might also be more. The obtained $\mathrm{IC}_{50}$ values of 1-3, the success of oxazolidinones as antimicrobial and the relatively less toxic nature of $\mathrm{L}$ on human cells, on its own $\left(\mathrm{IC}_{50}>1000 \mu \mathrm{M}\right.$ in MCF-7), warrants that the complexes are worth tuning with respect to the oxazolidinone and the labile ligands.

\section{Conclusions}

We found that the $\mathrm{CO}_{2}$ present in air is able to convert a pyridine containing amino alcohol into an oxazolidinone, in the presence of $\mathrm{SOCl}_{2}$ as an electrophile. The compound obtained, 3-(pyridin-2-ylmethyl)oxazolidin-2-one, may act as a ligand to synthesize late $3 \mathrm{~d}, 4 \mathrm{~d}$ and $5 \mathrm{~d}$ transition metal complexes, which would generate potential new candidates in catalysis and therapeutics. The ligand synthetic method is a simple way to fix atmospheric $\mathrm{CO}_{2}$ in organic synthesis. The three metal complexes generated as a proof of concept with the synthesized ligand without tuning it any further, showed that the $\mathrm{Cu}^{\mathrm{II}}$ complex (1) has some degree of selectivity for the MCF-7 cancer cell line. The platinum complex (2) is the most toxic among the three against both the MCF-7 and A549 cell lines, yet it is not as toxic as cisplatin, which might be good to check upon, since it has scope for rendering reduced side effects, due to the ligand being an oxazolidinone, with much less toxicity. The $\mathrm{Pd}^{\mathrm{II}}$ complex (3) is successful in the $\mathrm{C}-\mathrm{C}$ bond cross coupling reaction of activated and deactivated aryl bromides, and has scope for tuning, with very simple synthetic modifications. The results warrant further investigation, to tune the ligand and generate metal complexes which may have potential in catalysis and therapeutics.

\section{Experimental section}

\section{Material and methods}

All the chemicals and solvents used for this work were purchased from commercial sources. The solvents were distilled and dried, prior to use. Silica gel 60-120 mesh size (Merck-India) was used for the column chromatography. The UV-visible measurements were done using a Perkin Elmer Lambda 35 spectrophotometer. The FT-IR spectra were recorded using a Perkin-Elmer 120-000A, in $\mathrm{KBr}$ pellets. The ${ }^{1} \mathrm{H}$ and ${ }^{13} \mathrm{C}$ NMR spectra were measured using either a JEOL ECS $400 \mathrm{MHz}$ or Bruker Avance III spectrometer $500 \mathrm{MHz}$, at room temperature. The chemical shifts are reported in parts per million (ppm). The ${ }^{13} \mathrm{C}$ NMR spectra recorded are proton decoupled. The elemental analyses were performed on a Perkin Elmer Inc. EA 2400 CHNS series. The electro-spray ionization mass spectra were recorded using a Micromass Q-Tof microTM, Waters, by +ve mode electrospray ionization. The synthetic yields reported are of the isolated, analytically pure compounds. The Suzuki-Miyaura crosscoupling reactions were performed with a conventional heating method, as well as in a microwave (Anton Paar Monowave 300). The microwave reactions were performed in $10 \mathrm{~mL}$ Teflon capped glass vials. All the reactions in the microwave were carried out at $80{ }^{\circ} \mathrm{C}$ for a certain period of time (based on the completion of the reaction) while the pressure and microwave power were varied. The maximum pressure reached was 8 bar and the microwave power reached up to $46 \mathrm{~W}$.

Caution! Perchlorate salts are explosive and corrosive, so special care should be given for handling these compounds.

\section{Synthesis of ligands and their precursors}

Synthesis of 2-(pyridin-2-ylmethylamino)ethanol. It was synthesised according to a previously reported procedure. ${ }^{80}$ To a methanolic solution $(20 \mathrm{~mL})$ of pyridine-2-carboxaldehyde $(2.14 \mathrm{~g}$, $20 \mathrm{mmol}$ ), 2-aminoethanol (1.22 g, $20 \mathrm{mmol}$ ) was added drop wise in ice cold conditions. The resulting solution was then allowed to come to ambient temperature slowly and stirred for two hours. It was then subsequently treated with $\mathrm{NaBH}_{4}(1.89 \mathrm{~g}, 50 \mathrm{mmol})$ in small portions. After an additional $2 \mathrm{~h}$, the reaction mixture was concentrated to about $20 \mathrm{~mL}$, using a rotary evaporator. The remaining solution was added to $30 \mathrm{~mL}$ water and extracted with DCM $(3 \times 20 \mathrm{~mL})$. The organic layer was separated and subsequently dried with $\mathrm{Na}_{2} \mathrm{SO}_{4}$. Filtration and evaporation of the solvent gave the desired product. Yield. $1.8 \mathrm{~g}(60 \%)$. 
${ }^{1} \mathrm{H} \mathrm{NMR}\left(\mathrm{CDCl}_{3}, 400 \mathrm{MHz}\right) \delta 8.52(\mathrm{~d}, J=4.88 \mathrm{~Hz}, 1 \mathrm{H}, \mathrm{ArH}), 7.62$ (m, 1H, ArH), 7.24 (m, 1H, ArH), 7.16 (m, 1H, ArH), 3.91 (s, 2H, $\left.\mathrm{CH}_{2} \mathrm{NH}\right), 3.65\left(\mathrm{t}, J=4.88 \mathrm{~Hz}, 2 \mathrm{H}, \mathrm{CH}_{2}\right), 2.82(\mathrm{t}, J=4.88 \mathrm{~Hz}, 2 \mathrm{H}$, $\mathrm{CH}_{2}$ ).

Synthesis of 3-(pyridin-2-ylmethyl)oxazolidin-2-one (L). $1.6 \mathrm{~g}$ (10.5 mmol) of 2-(pyridin-2-ylmethylamino)ethanol was taken and $1 \mathrm{~mL}$ of $\mathrm{SOCl}_{2}$ added drop wise under ice cooled conditions, and stirred for 1 day at $25{ }^{\circ} \mathrm{C}$. Then, the excess $\mathrm{SOCl}_{2}$ was evaporated at reduced pressure, resulting in a yellow solid. It was then dissolved in $20 \mathrm{~mL}$ of water and the $\mathrm{pH}$ was adjusted to 7 . The solution was extracted with DCM $(3 \times 20 \mathrm{~mL})$ and the organic layer was separated and subsequently dried with $\mathrm{Na}_{2} \mathrm{SO}_{4}$. Filtration and evaporation of the solvent gave 3-(pyridin-2-ylmethyl)oxazolidin-2-one. Yield. $1.10 \mathrm{~g}$ (60\%). ${ }^{1} \mathrm{H}$ NMR $\left(\mathrm{CDCl}_{3}, 400 \mathrm{MHz}\right) \delta 8.56(\mathrm{~d}, J=4.88 \mathrm{~Hz}, 1 \mathrm{H}, \operatorname{ArH})$, 7.69 (m, 1H, ArH), 7.34 (m, 1H, ArH), 7.23 (m, 1H, ArH), 4.55 $\left(\mathrm{s}, 2 \mathrm{H}, \mathrm{CH}_{2} \mathrm{~N}\right), 4.37\left(\mathrm{t}, J=7.9 \mathrm{~Hz}, 2 \mathrm{H}, \mathrm{CH}_{2}\right), 3.64(\mathrm{t}, J=6.72 \mathrm{~Hz}$, $\left.2 \mathrm{H}, \mathrm{CH}_{2}\right) \mathrm{ppm}$ (Fig. S4, ESI $\left.\dagger\right) .{ }^{13} \mathrm{C} \mathrm{NMR}\left(\mathrm{CDCl}_{3}, 125 \mathrm{MHz}\right) \delta$ $158.3,155.4,149,136.7,122.3,121.7,61.64,49.39,44.3$ ppm (Fig. S5, ESI $\dagger$ ).

Synthesis of $\left[\mathrm{Cu}(\mathrm{L})_{2}\left(\mathrm{ClO}_{4}\right)_{2}\right]$ (1). To a $6 \mathrm{~mL}$ methanolic solution of ligand $\mathrm{L}(0.348 \mathrm{~g}, 1.97 \mathrm{mmol}), \mathrm{Cu}\left(\mathrm{ClO}_{4}\right)_{2} \cdot 6 \mathrm{H}_{2} \mathrm{O}$ $(0.364 \mathrm{~g}, 0.98 \mathrm{mmol})$ in $10 \mathrm{~mL}$ methanol was added. Immediately the solution turned green. The solution was then stirred at room temperature for $4 \mathrm{~h}$ followed by standing for $48 \mathrm{~h}$. A blue coloured, crystalline compound separated. The isolated yield was $0.317 \mathrm{~g}, 52 \%$. M.p. $176{ }^{\circ} \mathrm{C}$. Anal. calcd for $\mathrm{C}_{18} \mathrm{H}_{20} \mathrm{Cl}_{2} \mathrm{~N}_{4} \mathrm{O}_{12} \mathrm{Cu}$ : C, 34.94; H, 3.26; N, 9.05. Found: C, 34.88; H, 3.21; N, 8.86\%. IR $\left(\mathrm{KBr}, \mathrm{cm}^{-1}\right) 3437$ (br, m), $3096(\mathrm{w}), 2359(\mathrm{w}), 2024(\mathrm{w}), 1671$ (s), 1609 (m), 1500 (s), 1464 (m), 1448 (m), 1373 (m), 1330 (w), 1274 (s), $1098(\mathrm{~s}), 932(\mathrm{~m}), 821(\mathrm{~m}), 780(\mathrm{~m}), 754(\mathrm{~m}), 624(\mathrm{~s}), 557(\mathrm{~m})$. UV-vis (DMF) $\lambda(\mathrm{nm})\left(\varepsilon / \mathrm{dm}^{3} \mathrm{~mol}^{-1} \mathrm{~cm}^{-1}\right) 461$ (14), 260 (6488). ESI-MS calcd for $\left[\mathrm{M}-\mathrm{ClO}_{4}{ }^{-}\right]^{+} 518.03$ found 518.12.

Synthesis of trans-[Pt(L)(DMSO)Cl $\left.\mathbf{C l}_{2}\right]$ (2). Ligand L $(0.134 \mathrm{~g}$, $0.76 \mathrm{mmol}$ ) was dissolved in $4 \mathrm{~mL} \mathrm{DCM}$ and cis-[Pt(DMSO) $\left.{ }_{2} \mathrm{Cl}_{2}\right]$ $(0.320 \mathrm{~g}, 0.76 \mathrm{mmol})$ dissolved in $50 \mathrm{~mL}$ of DCM. The cis$\left[\mathrm{Pt}(\mathrm{DMSO})_{2} \mathrm{Cl}_{2}\right]$ solution was slowly added to the ligand solution under stirring conditions. The solution was then refluxed for $4 \mathrm{~h}$ and the solution was then evaporated under reduced pressure. A yellowish sticky mass was obtained, which was treated with $0.1 \mathrm{M} \mathrm{HCl}$ and then refrigerated overnight. After several washings with ether, a yellow solid product was obtained. A yellow, single crystal was obtained from the DCMhexane layering. The yield of the isolated pure product was 0.260 g, $78 \%$. M.p. $162{ }^{\circ} \mathrm{C}$. Anal. calcd for $\mathrm{C}_{11} \mathrm{H}_{16} \mathrm{Cl}_{2} \mathrm{~N}_{2} \mathrm{O}_{3}$ SPt: C, 25.3; H, 3.09; N, 5.36. Found: C, 24.94; H, 3.17; N, 5.14\%. ${ }^{1} \mathrm{H} \mathrm{NMR}\left(\mathrm{CDCl}_{3}, 400 \mathrm{MHz}\right) \delta 8.83(\mathrm{~m}, 1 \mathrm{H}, \mathrm{ArH}), 7.92(\mathrm{~m}, 1 \mathrm{H}$, ArH), 7.59 (d, $J=7.5 \mathrm{~Hz}, 1 \mathrm{H}, \operatorname{ArH}), 7.46$ (m, 1H, ArH), 5.28 $\left(\mathrm{s}, 2 \mathrm{H}, \mathrm{CH}_{2} \mathrm{~N}\right), 4.41\left(\mathrm{~m}, 2 \mathrm{H}, \mathrm{CH}_{2}\right), 3.59\left(\mathrm{~m}, 2 \mathrm{H}, \mathrm{CH}_{2}\right), 3.47(\mathrm{~s}, 6 \mathrm{H}$, $\left.\mathrm{CH}_{3} \mathrm{CH}_{3} \mathrm{SO}\right)$ ppm. ${ }^{13} \mathrm{C} \mathrm{NMR}\left(\mathrm{CDCl}_{3}, 125 \mathrm{MHz}\right) \delta 158.3,157.3$, $152.4,139.9,126.7,125,62.26,50.16,44.56,43.65$ ppm. IR (KBr, cm $\left.{ }^{-1}\right) 3553(\mathrm{br}), 3014(\mathrm{~m}), 2917$ (m), 1742 (s), 1609 (m), 1484 (s), 1445 (s), 1304 (w), 1322 (w), 1267 (s), 1148 (s), 1030 (s), $938(\mathrm{w}), 762(\mathrm{~m}), 751(\mathrm{~s}), 696(\mathrm{~m}), 539(\mathrm{w}), 442(\mathrm{~s})$. UV-vis (MeCN) $\lambda(\mathrm{nm})\left(\varepsilon / \mathrm{dm}^{3} \mathrm{~mol}^{-1} \mathrm{~cm}^{-1}\right) 439$ (12), 314 (266), 263 (5575). ESIMS calcd for $\left[\mathrm{M}+\mathrm{Na}^{+}\right] 543.98$ found 545.03 .
Synthesis of trans- $\left[\mathbf{P d}(\mathrm{L})_{2} \mathbf{C l}_{2}\right]$ (3). Ligand L $(0.237 \mathrm{~g}, 0.5 \mathrm{mmol})$ was dissolved in $5 \mathrm{~mL}$ acetonitrile and $\left[\mathrm{Pd}\left(\mathrm{MeCN}_{2} \mathrm{Cl}_{2}\right](0.130 \mathrm{~g}\right.$, $0.5 \mathrm{mmol})$ dissolved in $50 \mathrm{~mL}$ of DCM. The $\left[\mathrm{Pd}(\mathrm{MeCN})_{2} \mathrm{Cl}_{2}\right]$ solution was slowly added to the ligand solution under stirring. The solution was then refluxed for $4 \mathrm{~h}$. Orange coloured crystals were obtained from the acetonitrile solution. The isolated yield was $0.127 \mathrm{~g}, 48 \%$. M.p. $190{ }^{\circ} \mathrm{C}$. Anal. calcd for $\mathrm{C}_{18} \mathrm{H}_{20} \mathrm{Cl}_{2} \mathrm{~N}_{4} \mathrm{O}_{4} \mathrm{Pd}$ : C, 40.5; H, 3.78; N, 10.5. Found C, 39.94; H, 3.81; N, 10.2\%. ${ }^{1} \mathrm{H} \mathrm{NMR}\left(\mathrm{CDCl}_{3}, 400 \mathrm{MHz}\right) \delta 9.21(\mathrm{~d}, J=5.36 \mathrm{~Hz}, 1 \mathrm{H}, \mathrm{ArH}), 8.87$ (d, $J=5.32 \mathrm{~Hz}, 1 \mathrm{H}, \operatorname{ArH}), 8.07$ (m, 2H, ArH), 7.67 (m, 4H, ArH), $5.50\left(\mathrm{~s}, 2 \mathrm{H}, \mathrm{CH}_{2} \mathrm{~N}\right), 5.11\left(\mathrm{~s}, 2 \mathrm{H}, \mathrm{CH}_{2} \mathrm{~N}\right), 4.37\left(\mathrm{~m}, 4 \mathrm{H}, \mathrm{CH}_{2}\right), 3.53$ (m, $\left.4 \mathrm{H}, \mathrm{CH}_{2}\right), 3.47$ (s, 6H, $\left.\mathrm{CH}_{3} \mathrm{CH}_{3} \mathrm{SO}\right) \mathrm{ppm} .{ }^{13} \mathrm{C} \mathrm{NMR}\left(\mathrm{CDCl}_{3}\right.$, $100 \mathrm{MHz}) \delta 158.4,156.2,152.4,140.4,125.9,124.9,62.19,49.80$, 44.56 ppm. IR (KBr, cm $\left.{ }^{-1}\right) 3481$ (br), 3076 (m), 2891 (m), 1748 (s), 1607 (s), 1571 (m), 1485 (s), 1433 (s), 1412 (s), 1361 (m), 1275 (s), 1249 (s), 1207 (m), 1154 (w), 1085 (w), 1085 (s), 1033 (s), 970 (m), $944(\mathrm{~m}), 885(\mathrm{w}), 825(\mathrm{~m}), 771(\mathrm{~m}), 766(\mathrm{~s}), 697(\mathrm{~m}), 660(\mathrm{w}), 542$ (w), 445 (s). UV-vis (MeCN) $\lambda(\mathrm{nm})\left(\varepsilon / \mathrm{dm}^{3} \mathrm{~mol}^{-1} \mathrm{~cm}^{-1}\right) 400(241)$, 318 (323), 223 (157934). ESI-MS calcd for $\left[\mathrm{M}-\mathrm{Cl}^{-}\right]^{+} 498.95$ found 499.14 .

\section{X-ray crystallographic study}

Single crystals of 1-3 were mounted using loops on the goniometer head of a Bruker Kappa Apex II CCD Duo diffractometer with graphite monochromated Mo-K $\alpha$ radiation $(0.71073 \AA)$ and the data were collected at a temperature of $100 \mathrm{~K}$. An empirical multi-scan absorption correction was performed using SADABS. ${ }^{81}$ The structures were solved by direct methods and all the non-hydrogen atoms were refined anisotropically by full matrix least-squares on F2. The hydrogen atoms were calculated and fixed using SHELXL-97, after hybridization of all the non-hydrogen atoms. ${ }^{82}$ The ball and stick diagrams were made using Diamond version 2.0f. CCDC 956432 (1) and 956433 (2).

\section{Lipophilicity measurement}

The partition coefficients of the three complexes in an octanolwater system were determined using a standard shake-flask method. ${ }^{83}$ Octanol and phosphate buffer $(20 \mu \mathrm{M})$ (each $3 \mathrm{~mL}$ ) were pre-equilibrated for 8 hours before the experiment. ${ }^{84}$ After equilibration, the solid samples were added to the mixture of solvents and shaken on a dancing shaker overnight, at room temperature. After that, the tubes were centrifuged and left undisturbed for an hour. Aliquots of the aqueous and octanol layers were pipetted out separately and the absorbance measured using UV-vis spectroscopy. The concentration of the substances in each layer was calculated using the respective molar extinction coefficients of 1-3.

\section{Cell lines and culture condition}

The human breast adenocarcinoma cell line (MCF-7), human lung carcinoma cell line (A549) and mouse embryonic fibroblast cell line (NIH 3T3) were kind donations of Dr Jayasri Das Sarma and Dr Tapas Sengupta, Department of Biological Sciences, IISER-Kolkata, India. The cell lines were maintained in the logarithmic phase at $37{ }^{\circ} \mathrm{C}$ in a $5 \%$ carbon dioxide 
atmosphere, using a culture media containing DMEM, 10\% foetal bovine serum (GIBCO) and antibiotics (100 units $\mathrm{mL}^{-1}$ penicillin and $100 \mathrm{mg} \mathrm{mL} \mathrm{m}^{-1}$ streptomycin).

\section{Cell viability assay}

The cytotoxicity of complexes 1-3 on the MCF-7 and A549 cell lines were evaluated by the MTT (tetrazolium salt reduction) assay. ${ }^{85}$ Briefly, $6 \times 10^{3}$ cells per well were seeded in 96-well plates in growth medium $(200 \mathrm{~mL})$ and then incubated at $37{ }^{\circ} \mathrm{C}$ in a $5 \%$ carbon dioxide atmosphere. After $48 \mathrm{~h}$, the medium was removed and replaced with a fresh one and the compounds to be studied were added at appropriate concentrations. Triplicates for each concentration were used in the wells. The compounds to be added were solubilized in media, or PBS containing DMSO (when needed), such that the concentration of DMSO in each well should not exceed $0.2 \%$. Cisplatin was dissolved in DMSO just before the experiment and a calculated amount of the drug solution was added to the growth medium containing cells, such that the final DMSO concentration in the wells was no more than $0.2 \%$. After $48 \mathrm{~h}$, the media containing compound was removed and fresh media was added to each well and successively treated with $20 \mu \mathrm{L}$ of a $2 \mathrm{mg} \mathrm{mL}^{-1} \mathrm{MTT}$ in saline solution, followed by $3 \mathrm{~h}$ of incubation at $37{ }^{\circ} \mathrm{C}$ in a $5 \%$ carbon dioxide atmosphere. After $3 \mathrm{~h}$, the media were removed and $100 \mu \mathrm{L}$ of DMSO (molecular biology grade) added to each well. The inhibition of cell growth induced by the tested complexes was detected by measuring the absorbance of each well at $515 \mathrm{~nm}^{86,87}$ using a BIOTEK ELx800 plate reader. All the experiments had the respective controls and standards, as needed. The $\mathrm{IC}_{50}$ values represent the drug concentration that reduces the mean absorbance at $515 \mathrm{~nm}$ to $50 \%$, as compared to the untreated control wells.

\section{Catalytic study}

\section{General procedure for the Suzuki-Miyaura cross coupling reaction}

By conventional heating method. A typical $50 \mathrm{~mL}$ round bottom flask containing a magnetic stir bar was charged with phenylboronic acid $(0.091 \mathrm{~g}, 0.75 \mathrm{mmol})$ and $\mathrm{Cs}_{2} \mathrm{CO}_{3}(0.488 \mathrm{~g}$, $1.5 \mathrm{mmol})$. The aryl halide $(0.5 \mathrm{mmol})$ in EtOH $(5 \mathrm{~mL})$ was added to it. The catalyst (palladium complex) solution in EtOH was added, varying the loading percentage from $0.2 \mathrm{~mol} \%$ to $1 \mathrm{~mol} \%$, with respect to the aryl halide. The resulting mixture was refluxed and after completion of the reaction, the solvent was evaporated under a reduced pressure. The residue was diluted with water $(30 \mathrm{~mL})$ and extracted with dichloromethane $(3 \times 20 \mathrm{~mL})$. The organic layer was dried with $\mathrm{Na}_{2} \mathrm{SO}_{4}$ and the solvent was removed in vacuo. The resulting product was purified by silica gel column chromatography (mesh size 60-100) using either hexane or a dichloromethane-hexane mixture $(3: 1)$ depending on the product polarity. After column chromatography, the isolated yield was calculated.

By microwave method. A typical Teflon capped $10 \mathrm{~mL}$ glass vial, containing a magnetic stir bar was charged with phenylboronic acid (0.091 g, $0.75 \mathrm{mmol})$ and $\mathrm{Cs}_{2} \mathrm{CO}_{3}(0.488 \mathrm{~g}, 1.5 \mathrm{mmol})$.
The aryl halide $(0.5 \mathrm{mmol})$ in EtOH $(5 \mathrm{~mL})$ was added to it. The catalyst (palladium complex) solution in EtOH was added, varying the loading percentage from $0.2 \mathrm{~mol} \%$ to $1 \mathrm{~mol} \%$ with respect to the aryl halide. The resulting mixture was warmed at $80{ }^{\circ} \mathrm{C}$ for $10-45 \mathrm{~min}$, under a standard irradiation mode. After the completion of the reaction, the solvent was evaporated under a reduced pressure. The residue was diluted with water $(30 \mathrm{~mL})$ and extracted with dichloromethane $(3 \times 20 \mathrm{~mL})$. The organic layer was dried with $\mathrm{Na}_{2} \mathrm{SO}_{4}$ and the solvent was removed in vacuo. The resulting product was purified by silica gel column chromatography (mesh size 60-100) using either hexane or a dichloromethane-hexane mixture $(3: 1)$ depending on the product polarity. After column chromatography, the isolated yield was calculated.

Biphenyl. White solid. ${ }^{1} \mathrm{H}$ NMR (CDCl3, $\left.400 \mathrm{MHz}\right) \delta 7.63$ (d, $J=7.64 \mathrm{~Hz}, 4 \mathrm{H}, \mathrm{ArH}), 7.48(\mathrm{t}, J=7.64 \mathrm{~Hz}, 4 \mathrm{H}, \operatorname{ArH}), 7.38$ $(\mathrm{t}, J=6.88 \mathrm{~Hz}, 2 \mathrm{H}, \mathrm{ArH}) \mathrm{ppm}$ (Fig. S6, ESI $\dagger) .{ }^{13} \mathrm{C} \mathrm{NMR}\left(\mathrm{CDCl}_{3}\right.$, $100 \mathrm{MHz}) \delta$ 141, 128.9, 127.4, 127.3 ppm (Fig. S7, ESI $\dagger$ ).

4-Methylbiphenyl. White solid. ${ }^{1} \mathrm{H} \mathrm{NMR}\left(\mathrm{CDCl}_{3}, 400 \mathrm{MHz},\right)$ 7.51 (d, $J=7.64 \mathrm{~Hz}, 2 \mathrm{H}, \operatorname{ArH}), 7.42$ (d, $J=7.64 \mathrm{~Hz}, 2 \mathrm{H}, \operatorname{ArH})$, $7.36(\mathrm{t}, J=7.64 \mathrm{~Hz}, 2 \mathrm{H}, \mathrm{ArH}), 7.25(\mathrm{t}, J=7.64 \mathrm{~Hz}, 1 \mathrm{H}, \mathrm{ArH}), 7.16$ (d, $J=7.6 \mathrm{~Hz}, 2 \mathrm{H}, \mathrm{ArH}), 2.31$ (s, 3H, $\mathrm{CH}_{3}$ ) ppm (Fig. S8, ESI $\dagger$ ). ${ }^{13} \mathrm{C} \mathrm{NMR}\left(\mathrm{CDCl}_{3}, 100 \mathrm{MHz}\right) \delta 141,138,136,129,128,126,21$ ppm (Fig. S9, ESI $\dagger$ ).

4-Methoxybiphenyl. White solid. ${ }^{1} \mathrm{H} \mathrm{NMR}\left(\mathrm{CDCl}_{3}, 400 \mathrm{MHz}\right) \delta$ $7.59(\mathrm{~m}, 2 \mathrm{H}, \mathrm{ArH}), 7.45(\mathrm{t}, J=7.64 \mathrm{~Hz}, 2 \mathrm{H}, \mathrm{ArH}), 7.34(\mathrm{t}, J=7.64$ $\mathrm{Hz}, 1 \mathrm{H}, \mathrm{ArH}), 7.01$ (d, $J=8.4 \mathrm{~Hz}, 2 \mathrm{H}, \mathrm{ArH}), 3.87$ (s, 3H, $\mathrm{CH}_{3}$ ) ppm (Fig. S10, ESI $\dagger$ ). ${ }^{13} \mathrm{C} \mathrm{NMR}\left(\mathrm{CDCl}_{3}, 100 \mathrm{MHz}\right) \delta$ 159, 141, 133, 129, 128, 126.8, 126.7, 114, 56 ppm (Fig. S11, ESI $\dagger$ ).

4-Acetylbiphenyl. White solid. ${ }^{1} \mathrm{H}$ NMR $\left(\mathrm{CDCl}_{3}, 400 \mathrm{MHz}\right) \delta$ $8.05(\mathrm{~d}, J=8.4 \mathrm{~Hz}, 2 \mathrm{H}, \mathrm{ArH}), 7.70(\mathrm{~d}, J=8.4 \mathrm{~Hz}, 2 \mathrm{H}, \mathrm{ArH}), 7.64$ (t, $J=2.28 \mathrm{~Hz}, 2 \mathrm{H}, \operatorname{ArH}), 7.49(\mathrm{t}, J=6.88 \mathrm{~Hz}, 2 \mathrm{H}, \mathrm{ArH}), 7.42$ $(\mathrm{t}, J=6.88 \mathrm{~Hz}, 1 \mathrm{H}, \mathrm{ArH}), 2.64\left(\mathrm{~s}, 3 \mathrm{H}, \mathrm{CH}_{3}\right) \mathrm{ppm}$ (Fig. S12, ESI $\dagger$ ). ${ }^{13} \mathrm{C} \mathrm{NMR}\left(\mathrm{CDCl}_{3}, 100 \mathrm{MHz}\right) \delta 197,146,140,135,129.07,129.04$, 128.9, 127.40, 127.30, 27 ppm (Fig. S13, ESI $\dagger$ ).

4-Nitrobiphenyl. Light yellow solid. ${ }^{1} \mathrm{H}$ NMR $\left(\mathrm{CDCl}_{3}, 400\right.$ $\mathrm{MHz}) \delta 8.31(\mathrm{~d}, J=9.16 \mathrm{~Hz}, 2 \mathrm{H}, \mathrm{ArH}), 7.75(\mathrm{~d}, J=8.4 \mathrm{~Hz}, 2 \mathrm{H}$, ArH), 7.64 (d, $J=6.88 \mathrm{~Hz}, 2 \mathrm{H}, \operatorname{ArH}), 7.52(\mathrm{~m}, 3 \mathrm{H}, \mathrm{ArH}) \mathrm{ppm}$ (Fig. S14, ESI $\dagger) .{ }^{13} \mathrm{C} \mathrm{NMR}\left(\mathrm{CDCl}_{3}, 100 \mathrm{MHz}\right) \delta 146,139,133$, 129.2, 128.8, 127.9, 127.4, 119, 111 ppm (Fig. S15, ESI $\dagger$ ).

4-Cyanobiphenyl. White solid. ${ }^{1} \mathrm{H}$ NMR $\left(\mathrm{CDCl}_{3}, 400 \mathrm{MHz}\right) \delta$ $7.74(\mathrm{~m}, 4 \mathrm{H}, \mathrm{ArH}), 7.60(\mathrm{~d}, J=6.88 \mathrm{~Hz}, 2 \mathrm{H}, \mathrm{ArH}), 7.51(\mathrm{t}, J=6.88$ $\mathrm{Hz}, 2 \mathrm{H}, \mathrm{ArH}$ ), 7.45 (t, $J=7.64 \mathrm{~Hz}, 1 \mathrm{H}, \mathrm{ArH})$ ppm (Fig. S16, ESI $\dagger$ ). ${ }^{13} \mathrm{C} \mathrm{NMR}\left(\mathrm{CDCl}_{3}, 100 \mathrm{MHz}\right) \delta 148,147,139,129.3,129.1,127.9$, 127.9, 127.5, 124 ppm (Fig. S17, ESI $\dagger$ ).

2-Phenylpyridine. Yellow oil. ${ }^{1} \mathrm{H}$ NMR $\left(\mathrm{CDCl}_{3}, 400 \mathrm{MHz}\right) \delta$ 8.71 (m, 1H, ArH), 7.99 (m, 2H, ArH), 7.77 (m, 2H, ArH), 7.50 (m, 3H, ArH) 7.27 (m, 1H, ArH) ppm (Fig. S18, ESI $\dagger$ ). ${ }^{13} \mathrm{C}$ NMR $\left(\mathrm{CDCl}_{3}, 100 \mathrm{MHz}\right) \delta 157,150,139,137,128.9,128.7,127,122$, 120 ppm (Fig. S19, ESI $\dagger$ ). 


\section{Acknowledgements}

We sincerely acknowledge the DST, India for funding (Vide Project no-SR/S1/IC-36/2010). We are also thankful to the IISER Kolkata, for the financial and infra-structural support, including the NMR and single crystal X-ray facilities. We are thankful to Dr Tapas K. Sengupta and Dr Jayasri Das Sarma for the donation of the MCF-7, NIH 3T3 and A549 cell lines. We also thank Dr Venkataramanan Mahalingam for the microwave reactor used in this work. A. S. sincerely thanks the IISER Kolkata for a research fellowship. S. B. and S. K. D. thank the CSIR-India for research fellowships. S. K. acknowledges the UGC for a research fellowship.

\section{References}

1 D. A. Evans, S. J. Miller and T. Lectka, J. Am. Chem. Soc., 1993, 115, 6460-6461.

2 S. Kanemasa, Y. Oderaotoshi, S.-i. Sakaguchi, H. Yamamoto, J. Tanaka, E. Wada and D. P. Curran, J. Am. Chem. Soc., 1998, 120, 3074-3088.

3 D. A. Evans, J. S. Johnson and E. J. Olhava, J. Am. Chem. Soc., 2000, 122, 1635-1649.

4 C. B. Shinisha and R. B. Sunoj, J. Am. Chem. Soc., 2010, 132, 12319-12330.

5 J. S. Johnson and D. A. Evans, Acc. Chem. Res., 2000, 33, 325-335.

6 D. A. Evans, C. W. Downey and J. L. Hubbs, J. Am. Chem. Soc., 2003, 125, 8706-8707.

7 D. A. Evans, D. Seidel, M. Rueping, H. W. Lam, J. T. Shaw and C. W. Downey, J. Am. Chem. Soc., 2003, 125, 12692-12693.

8 D. A. Evans, K. A. Scheidt, J. N. Johnston and M. C. Willis, J. Am. Chem. Soc., 2001, 123, 4480-4491.

9 K. Muniz and M. Nieger, Chem. Commun., 2005, 2729-2731.

10 I. Almodovar, C. H. Hoevelmann, J. Streuff, M. Nieger and K. Muniz, Eur. J. Org. Chem., 2006, 704-712.

11 K. Gedrich, M. Heitbaum, A. Notzon, I. Senkovska, R. Froehlich, J. Getzschmann, U. Mueller, F. Glorius and S. Kaskel, Chem.-Eur. J., 2011, 17, 2099-2106.

12 B. A. Howell and E. W. Walles, Polym. Prepr. (Am. Chem. Soc., Div. Polym. Chem.), 1986, 27, 460-461.

13 S. Lundberg, S. Ayesa, O. Belda, I. Dorange, K. Ersmark, K. Hammer, P.-O. Johansson, S. Lindstroem, A. Rosenquist, B. Samuelsson, M. Baeck, I. Kvarnstroem, F. Waangsell and K. Bjoerklund, Medivir AB, Swed., WO 2010042030, 2010, p. 153.

14 B. H. Candon, M. Chessin and W. E. Lange, Purdue Frederick Co., US 3108045, 1963, p. 16.

15 M. E. Dyen and D. Swern, Chem. Rev., 1967, 67, 197-246.

16 G. P. Speranza and W. J. Peppel, J. Org. Chem., 1958, 23, 1922-1924.

17 G. Y. Lesher and A. R. Surrey, J. Am. Chem. Soc., 1955, 77, 636-641.

18 W. J. Close, J. Am. Chem. Soc., 1951, 73, 95-98.

19 J. E. Herweh and W. J. Kauffman, Tetrahedron Lett., 1971, 12, 809-812.
20 M. Kodaka, T. Tomohiro and H. Okuno, J. Chem. Soc., Chem. Commun., 1993, 81-82.

21 M. A. Casadei, M. Feroci, A. Inesi, L. Rossi and G. Sotgiu, J. Org. Chem., 2000, 65, 4759-4761.

22 Y. Du, Y. Wu, A.-H. Liu and L.-N. He, J. Org. Chem., 2008, 73, 4709-4712.

23 B. Gabriele, G. Salerno, D. Brindisi, M. Costa and G. P. Chiusoli, Org. Lett., 2000, 2, 625-627.

24 J. Paz, C. Perez-Balado, B. Iglesias and L. Munoz, J. Org. Chem., 2010, 75, 3037-3046.

25 W. B. Wright, Jr., J. Heterocycl. Chem., 1965, 2, 41-43.

26 S. Cutugno, G. Martelli, L. Negro and D. Savoia, Eur. J. Org. Chem., 2001, 517-522.

27 A. J. Duplantier, I. Efremov, J. Candler, A. C. Doran, A. H. Ganong, J. A. Haas, A. N. Hanks, K. G. Kraus, J. T. Lazzaro, J. Lu, N. Maklad, S. A. McCarthy, T. J. O’Sullivan, B. N. Rogers, J. A. Siuciak, D. K. Spracklin and L. Zhang, Bioorg. Med. Chem. Lett., 2009, 19, 2524-2529.

28 W. A. Gregory, D. R. Brittelli, C. L. J. Wang, M. A. Wuonola, R. J. McRipley, D. C. Eustice, V. S. Eberly, A. M. Slee, M. Forbes and P. T. Bartholomew, J. Med. Chem., 1989, 32, 1673-1681.

29 W. A. Gregory, D. R. Brittelli, C. L. J. Wang, H. S. Kezar, III, R. K. Carlson, C. H. Park, P. F. Corless, S. J. Miller, P. Rajagopalan, M. A. Wuonola, R. J. McRipley, V. S. Eberly, A. M. Slee and M. Forbes, J. Med. Chem., 1990, 33, 2569-2578.

30 C. H. Park, D. R. Brittelli, C. L. J. Wang, F. D. Marsh, W. A. Gregory, M. A. Wuonola, R. J. McRipley, V. S. Eberly, A. M. Slee and M. Forbes, J. Med. Chem., 1992, 35, 1156-1165.

31 J. A. Tucker, D. A. Allwine, K. C. Grega, M. R. Barbachyn, J. L. Klock, J. L. Adamski, S. J. Brickner, D. K. Hutchinson, C. W. Ford, G. E. Zurenko, R. A. Conradi, P. S. Burton and R. M. Jensen, J. Med. Chem., 1998, 41, 3727-3735.

32 S. D. Paget, B. D. Foleno, C. M. Boggs, R. M. Goldschmidt, D. J. Hlasta, M. A. Weidner-Wells, H. M. Werblood, E. Wira, K. Bush and M. J. Macielag, Bioorg. Med. Chem. Lett., 2003, 13, 4173-4177.

33 D. A. Evans, K. A. Scheidt and C. W. Downey, Org. Lett., 2001, 3, 3009-3012.

34 C. Ji, W. Lin, G. C. Moraski, J. A. Thanassi, M. J. Pucci, S. G. Franzblau, U. Mollmann and M. J. Miller, Bioorg. Med. Chem., 2012, 20, 3422-3428.

35 Y.-E. Kwon, J.-Y. Park and W.-K. Kim, Anticancer Res., 2007, 27, 321-326.

36 M. Micksch and T. Strassner, Eur. J. Inorg. Chem., 2012, 5872-5880.

37 M. Boudart, Chem. Rev., 1995, 95, 661-666.

38 T. P. Shiau, E. D. Turtle, C. Francavilla, N. J. Alvarez, M. Zuck, L. Friedman, D. J. R. O’Mahony, E. Low, M. B. Anderson, R. Najafi and R. K. Jain, Bioorg. Med. Chem. Lett., 2011, 21, 3025-3028.

39 M. L. H. Mantel, A. T. Lindhardt, D. Lupp and T. Skrydstrup, Chem.-Eur. J., 2010, 16, 5437-5442.

40 N. Miyaura and A. Suzuki, Chem. Rev., 1995, 95, 2457-2483. 41 A. Suzuki, J. Organomet. Chem., 2002, 653, 83-90. 
42 S. P. Stanforth, Tetrahedron, 1998, 54, 263-303.

43 A. F. Littke and G. C. Fu, Angew. Chem., Int. Ed., 2002, 41, 4176-4211.

44 R. B. Bedford, C. S. J. Cazin and D. Holder, Coord. Chem. Rev., 2004, 248, 2283-2321.

45 A. C. Frisch and M. Beller, Angew. Chem., Int. Ed., 2005, 44, 674-688.

46 L. Braun, P. Liptau, G. Kehr, J. Ugolotti, R. Froehlich and G. Erker, Dalton Trans., 2007, 1409-1415.

47 E. J. Garcia Suarez, A. Ruiz, S. Castillon, W. Oberhauser, C. Bianchini and C. Claver, Dalton Trans., 2007, 2859-2861.

48 S. K. Yen, L. L. Koh, H. V. Huynh and T. S. A. Hor, Dalton Trans., 2008, 699-706.

49 B. Punji, J. T. Mague and M. S. Balakrishna, Inorg. Chem., 2006, 45, 9454-9464.

50 B. Punji, J. T. Mague and M. S. Balakrishna, Inorg. Chem., 2007, 46, 10268-10275.

51 A. Ros, B. Estepa, A. Bermejo, E. Alvarez, R. Fernandez and J. M. Lassaletta, J. Org. Chem., 2012, 77, 4740-4750.

52 P. Stepnicka, J. Schulz, T. Klemann, U. Siemeling and I. Cisarova, Organometallics, 2010, 29, 3187-3200.

53 O. Piechaczyk, M. Doux, L. Ricard and P. Le Floch, Organometallics, 2005, 24, 1204-1213.

54 T. Mino, Y. Shirae, M. Sakamoto and T. Fujita, J. Org. Chem., 2005, 70, 2191-2194.

55 J. M. Chalker, C. S. C. Wood and B. G. Davis, J. Am. Chem. Soc., 2009, 131, 16346-16347.

56 L. Zhang, L. Wang, H. Li and P. Li, Synth. Commun., 2008, 38, 1498-1511.

57 H. Yan, P. Chellan, T. Li, J. Mao, K. Chibale and G. S. Smith, Tetrahedron Lett., 2013, 54, 154-157.

58 M. Basauri-Molina, S. Hernandez-Ortega, R. A. Toscano, J. Valdes-Martinez and D. Morales-Morales, Inorg. Chim. Acta, 2010, 363, 1222-1229.

59 H. Lebel, M. K. Janes, A. B. Charette and S. P. Nolan, J. Am. Chem. Soc., 2004, 126, 5046-5047.

60 N. Marion, O. Navarro, J. Mei, E. D. Stevens, N. M. Scott and S. P. Nolan, J. Am. Chem. Soc., 2006, 128, 4101-4111.

61 Z.-Y. Wang, G.-Q. Chen and L.-X. Shao, J. Org. Chem., 2012, 77, 6608-6614.

62 L. Ray, M. M. Shaikh and P. Ghosh, Organometallics, 2007, 26, 958-964.

63 T. Zhang, W. Wang, X. Gu and M. Shi, Organometallics, 2008, 27, 753-757.

64 W. Wei, Y. Qin, M. Luo, P. Xia and M. S. Wong, Organometallics, 2008, 27, 2268-2272.

65 H. Turkmen, R. Can and B. Cetinkaya, Dalton Trans., 2009, 7039-7044.

66 H. Ohta, T. Fujihara and Y. Tsuji, Dalton Trans., 2008, 379-385.
67 O. Diebolt, P. Braunstein, S. P. Nolan and C. S. J. Cazin, Chem. Commun., 2008, 3190-3192.

68 K.-E. Lee, H.-T. Jeon, S.-Y. Han, J. Ham, Y.-J. Kim and S. W. Lee, Dalton Trans., 2009, 6578-6592.

69 I. J. S. Fairlamb, A. R. Kapdi, A. F. Lee, G. Sanchez, G. Lopez, J. L. Serrano, L. Garcia, J. Perez and E. Perez, Dalton Trans., 2004, 3970-3981.

70 Y.-J. Kim, J.-H. Lee, T. Kim, J. Ham, Z. N. Zheng and S. W. Lee, Eur. J. Inorg. Chem., 2012, 6011-6017.

71 A. John, M. M. Shaikh, R. J. Butcher and P. Ghosh, Dalton Trans., 2010, 39, 7353-7363.

72 D. V. Aleksanyan, V. A. Kozlov, Y. V. Nelyubina, K. A. Lyssenko, L. N. Puntus, E. I. Gutsul, N. E. Shepel, A. A. Vasil'ev, P. V. Petrovskii and I. L. Odinets, Dalton Trans., 2011, 40, 1535-1546.

73 M. D. Santana, R. Garcia-Bueno, G. Garcia, G. Sanchez, J. Garcia, A. R. Kapdi, M. Naik, S. Pednekar, J. Perez, L. Garcia, E. Perez and J. L. Serrano, Dalton Trans., 2012, 41, 3832-3842.

74 N. T. S. Phan, D. S. M. Van and C. W. Jones, Adv. Synth. Catal., 2006, 348, 609-679.

75 W. M. Liu, D. W. Fowler, P. Smith and A. G. Dalgleish, Br. J. Cancer, 2010, 102, 115-123.

76 M.-S. Chua, L. R. Bernstein and S. K. S. So, Anticancer Res., 2006, 26, 1739-1744.

77 C. Tan, S. Lai, S. Wu, S. Hu, L. Zhou, Y. Chen, M. Wang, Y. Zhu, W. Lian, W. Peng, L. Ji and A. Xu, J. Med. Chem., 2010, 53, 7613-7624.

78 D. Pluim, R. C. A. M. van Waardenburg, J. H. Beijnen and J. H. M. Schellens, Cancer Chemother. Pharmacol., 2004, 54, 71-78.

79 A. Casini, F. Edafe, M. Erlandsson, L. Gonsalvi, A. Ciancetta, N. Re, A. Ienco, L. Messori, M. Peruzzini and P. J. Dyson, Dalton Trans., 2010, 39, 5556-5563.

80 S. Striegler and M. Dittel, Inorg. Chem., 2005, 44, 2728-2733.

81 G. M. Sheldrick, Z. Kristallogr., 2002, 217, 644-650.

82 G. M. Sheldrick, Int. Union Crystallogr., Crystallogr. Symp., 1991, 5, 145-157.

83 C. Zhang, Y. Wang and F. Wang, Bull. Korean Chem. Soc., 2007, 28, 1183-1186.

84 J. Sangster and A. D. Pelton, J. Phys. Chem. Ref. Data, 1987, 16, 509-561.

85 T. Mosmann, J. Immunol. Methods, 1983, 65, 55-63.

86 B. L. Lokeshwar, E. Escatel and B. Zhu, Curr. Med. Chem., 2001, 8, 271-279.

87 M. C. Alley, D. A. Scudiero, A. Monks, M. L. Hursey, M. J. Czerwinski, D. L. Fine, B. J. Abbott, J. G. Mayo, R. H. Shoemaker and M. R. Boyd, Cancer Res., 1988, 48, 589-601. 